\title{
KNOWLEDGE MANAGEMENT AND COLLABORATION EFFECTS: SOUTH-SOUTH NGO COLLABORATION: A CASE STUDY ON THE BRAZILIAN INTERDISCIPLINARY AIDS ASSOCIATION
}

\author{
Grace Keeney \\ Grenoble École de Management, France
}

\section{ABSTRACT}

In June 2008, the Brazilian Interdisciplinary AIDS Association (ABIA) and the Indian NGO SAHARA submitted a joint pre-grant opposition to the patent application of Tenofovir Disoproxil Fumarate in India. This joint action provides a pertinent case model of the potential effects of South-South cooperation between civil society groups. In this study, the aim sought to determine the practicality of the methodology and propositions developed in Resources, Knowledge and Influence: the Organizational Effects of Interorganizational Collaboration (Hardy et al., 2003) in predicting the types of collaboration effects that would result from the degree of "involvement" and "embeddedness" of a collaboration. Data collection came from archival research, participant observation research and interviews. Research tasks included an investigation on South-South Cooperation in the area of IP rights and AIDS, compiling an SLR on knowledge management and collaboration theories, creating a chronology of the collaboration and application of aforementioned methodology. Application included implementation of codification methodology based on "involvement" and "embeddedness" and (2) identification of types of effects in collaboration - strategic, knowledge creation or political. During data analysis, these effects were compared with the aims of collaboration. Results were then tested against propositions (Hardy 
et al., 2003) of the relationship between involvement and embeddedness and the collaborative effects. Findings support three propositions: (1) Collaborations with high levels of involvement will be positively associated with the acquisition of distinctive resources, (2) Collaborations with high levels of involvement and high levels of embeddedness will be positively associated with the creation of knowledge, (3) Collaborations that are highly embedded will be positively associated with an increase of influence.

Keywords: Knowledge Management. Collaboration Effects. AIDS. Non-Profits. South-South Cooperation

\section{INTRODUCTION}

On June $26^{\text {th }} 2008$ the Brazilian Interdisciplinary Association of AIDS (ABIA) submitted a pre-grant opposition to the patent application of Tenofovir Disoproxil Fumarate (tenofovir), an antiretroviral drug (ARV) used to combat the HIV virus at various levels. What made this case remarkable was where the opposition was submitted - not in Brazil, but rather in India. Among Indian and Brazilian civil society, this case was heralded as the first time a foreign patient group decided to oppose and Indian patent application (Anderson, 2008).

ABIA submitted the pre-grant opposition with the Centre for Residential Care \& Rehabilitation (SAHARA), an Indian AIDS-related advocacy group, on the grounds that an Indian patent of tenofovir would directly impact Brazil's capacity to produce and access affordable generic versions of the ARV (Médecins Sans Frontières, 2011, p. 50). This collaboration was partially developed by SAHARA's legal representative, the Lawyers Collective, an Indian public interest provider of legal services. The Lawyers Collective had already submitted a pre-grant opposition in India years prior to ABIA's and SAHARA's joint opposition. 
Brazilian and Indian activists from ABIA, SAHARA and the Lawyers Collective reasoned that a tenofovir patent in India would preclude Brazil from importing tenofovir or its constituent elements from Indian generic companies due to the resulting increase in prices for the proprietary version. At the time of the opposition, tenofovir cost US $\$ 1,387$ per patient per year in Brazil, whereas in India, the generic version of tenofovir cost only US $\$ 158$ (Anderson, 2008). Then, a palpable fear pervaded among Brazilians affected by AIDS that the government would not meet its constitutional responsibility to provide ARV treatment due to financial burden.

ABIA along with other Brazilian AIDS groups, had already filed a pre-grant opposition to tenofovir in December 2006 at the Brazilian patent office. "Although we are confident the tenofovir patent will not be granted in Brazil, we must ensure that the option of importing affordable generic versions from India remains open to our AIDS program," stated ABIA's general coordinator. "This will contribute to the sustainability of our national AIDS program's universal access policy, upon which 180,000 Brazilians depend on for their lives." (BS Reporter, 2009). An estimated 31,000 people living with HIV and/or AIDS (PLWHA) were expected to receive tenofovir via Brazil's national AIDS program by the end of 2008 (BS Reporter, 2009).

ABIA, SAHARA and the Lawyers Collective opposed the tenofovir patent, claiming no inventive step had taken place, as it was the result of combining salt (fumaric acid) to an existing compound (tenofovir disoproxil) (Médecins Sans Frontières, 2011, p. 50). India's Patents Act incorporates a provision against patenting minor improvements of known medicines in Section 3(d). The law permits any party (domestic or foreign) to submit pre-grant oppositions to patent applications. In 2006, other Indian AIDSrelated groups had also submitted a pre-grant opposition to tenofovir in India (Raaj, 2008).

In June 2009, the Brazilian Patent Office issued a final refusal of a patent for tenofovir. And in September 2009, several patent applications 
relating to the compounds in tenofovir were also rejected by the Indian Patent Office.

Considered a major victory for access to essential medicines, the joint action taken by ABIA and SAHARA provides a pertinent case model for the potential effects of cooperation between civil society groups of developing and emerging countries.

In this study, the aim is to evaluate the effects of (1) South-South inter-organizational cooperation and (2) access to essential medicines for PLWHA on the research areas of knowledge management and collaboration. ABIA's joint opposition with SAHARA against the patent application of Tenofovir in India is the case study of this article and the effects of this collaboration on ABIA are categorized as strategic effects, knowledge creation effects or political effects. This research was done in hopes that it would contribute to the little literature on South-South cooperation between civil society.

As a volunteer project assistant at ABIA, the writer of this paper observed that knowledge management practices also apply to non-profits, albeit the predominance of knowledge management literature on for-profits. In addition, the writer observed that ABIA's commitment to joint action with domestic and international groups resulted in the three effects listed in collaboration literature. Unable to find an empirical study on the effects of joint action between two NGOs from different developing countries, the writer intends to fill this gap in academic literature.

The aim of this study also aspires to contribute to the empowerment of PLWHA in the Global South, particularly the empowerment of the advocacy groups that represent them. Though unconventional, this joint strategy has had positive implications for both PLWHA in Brazil and ABIA at the organizational level. With a disproportionate concentration of the world's PLWHA, such strategies may be useful in securing access to AIDS medicines in the Global South.

The argumentation of this paper is divided in 5 parts. First, the context and the relevance of the topic are described via an evaluation of (1) 
AIDS in the developing world, (2) access to medicines and intellectual property rights in the developing world and (3) South-South cooperation among AIDS-related NGOs, exploring factors for South-South cooperation. Secondly, a systematic literature review on (1) knowledge management and non-profits and (2) collaboration is compiled. Thirdly, the study's research methodology is presented, incorporating a qualitative methodology adapted from Resources, Knowledge and Influence: the Organizational Effects of Interorganizational Collaboration (Hardy et al. 2003). The effects of the joint action opposed to the tenofovir patent application on ABIA are then tested against propositions of the same study (Hardy et al. 2003). The conclusion of the paper then discusses the implications and limitations of this case study.

\section{CONTEXT}

\subsection{AIDS IN THE DEVELOPING WORLD}

The first case of acquired immunodeficiency syndrome, or AIDS, was reported as pneumocystis pneumonia in 1981 in the Morbidity and Morality Weekly Report (1981 cited in Sepkowitz, 2001). Three decades later, almost 30 million people have died from AIDS-related causes (UNAIDS, 2010). Although AIDS-related deaths have been decreasing since its peak of 2.1 million per annum in 2004, 1.8 million AIDS-related deaths were documented in 2010 and 33.3 million people are categorized as People Living with HIV or AIDS (PLWHA). Of that total, more than $95 \%$ live in the developing world and 68\% in Sub-Sahara Africa (UNAIDS, 2010, p 25). (see Table 1) 


\begin{tabular}{l|l|l|l|l}
\hline Region & $\begin{array}{l}\text { Adults \& } \\
\text { children } \\
\text { living with } \\
\text { HIV/AIDS }\end{array}$ & $\begin{array}{l}\text { Adults \& } \\
\text { children } \\
\text { newly } \\
\text { infected }\end{array}$ & $\begin{array}{l}\text { Adult } \\
\text { prevalence* }\end{array}$ & $\begin{array}{l}\text { AIDS-related } \\
\text { deaths in } \\
\text { adults \& } \\
\text { children }\end{array}$ \\
\hline $\begin{array}{l}\text { Sub-Saharan } \\
\text { Africa }\end{array}$ & 22.5 million & 1.8 million & $5.0 \%$ & 1.3 million \\
\hline $\begin{array}{l}\text { North Africa } \\
\text { \& Middle East }\end{array}$ & 460,000 & 75,000 & $0.2 \%$ & 24,000 \\
\hline $\begin{array}{l}\text { South and } \\
\text { South-East } \\
\text { Asia }\end{array}$ & 4.1 million & 270,000 & $0.3 \%$ & 260,000 \\
\hline East Asia & 770,000 & 82,000 & $<0.1 \%$ & 36,000 \\
\hline Oceania & 57,000 & 4,500 & $0.3 \%$ & 1,400 \\
\hline $\begin{array}{l}\text { Central \& } \\
\text { South } \\
\text { America }\end{array}$ & 1.4 million & 92,000 & $0.5 \%$ & 58,000 \\
\hline Caribbean & 240,000 & 17,000 & $1.0 \%$ & 12,000 \\
\hline $\begin{array}{l}\text { Eastern } \\
\text { Europe \& } \\
\text { Central Asia }\end{array}$ & 1.4 million & 130,000 & $0.8 \%$ & 76,000 \\
\hline $\begin{array}{l}\text { North } \\
\text { America }\end{array}$ & 1.5 million & 70,000 & $0.5 \%$ & 26,000 \\
\hline $\begin{array}{l}\text { Western \& } \\
\text { Central } \\
\text { Europe }\end{array}$ & 820,000 & 31,000 & $0.2 \%$ & 8,500 \\
\hline Global Total & 33.3 million & 2.6 million & $0.8 \%$ & 1.8 million \\
\hline$\%$ an & & & & \\
\hline
\end{tabular}

*Proportion of adults aged 15-49 who are living with HIV/AIDS

\section{Chart 1: AIDS around the Globe}

Source: adapted from UNAIDS, 2010, pp. 20-21

The severity of the AIDS epidemic compelled the United Nations to commit to Goal 6a and b of the Millennium Development Goals: "Have halted by 2015 and begun to reverse the spread of HIV/AIDS" and 
"Achieve, by 2010, universal access to treatment for HIV/AIDS to all those who need it" (MDGs) (United Nations, n.d.). UNAIDS, the policymaker of AIDS-related international strategies, has targeted developing countries in order to meet its MDG obligations. It recognizes the link between poverty and the proliferation of diseases in the developing world, as well as the correlation between affluence and the reversal of the expansion of AIDS in the developed world. The world's richest countries have seen a turnaround in the spread of AIDS due to increase access to preventative and therapeutic treatment for PLWHA (UNAIDS, 2010, p. 96). Developing countries have historically lacked the mechanisms - medicines, infrastructure, R\&D and governance - to tackle such an epidemic and, thus, have been relatively ineffective in halting it (UNAIDS, 2010, p. 96). AIDS is, therefore, described as both the result and the cause of social problems in developing countries.

MDG 6b, furthermore, acknowledges that treatment precludes AIDS' expansion. Currently, the medical community treats HIV/AIDS with a combination of antiretroviral therapy ( $A R V s$ ) designed to combat the virus at various levels. ARVs inhibit the enzymes of HIV that involve replication and mutation. Although treatment does not cure the disease, it enables PLWHA to live normal lives and prevents the transfer of the disease from mother to child (ABIA, 2009, p. 10). Recently created ARV combination therapies waiting governmental approval are even being touted of impeding the transfer of the disease between sexual partners - making the eventual eradication of the disease seem more like a possibility (Harris, 2011). Empirical evidence attests to the potency of ARVs; rates of new infections are stabilizing in areas where nationwide preventative and therapeutic treatments are implemented (UNAIDS, 2010). Nonetheless, ARVs are expensive, and the newest, most innovative medicines are not available in all countries, particularly those in the developing world (Palella, Delaney \& Moorman, 1998, pp. 853-860).

\subsection{ACCESS TO ESSENTIAL MEDICINES AND IP RIGHTS IN THE}


DEVELOPING WORLD

ARV treatment has been the primary focus of AIDS reduction strategies because it has had the most potential among medical interventions to significantly decrease AIDS-related morbidity, mortality and the need for other health-related services (UN Millennium Project, 2005, p.79). Initially, developing countries' biggest hurdle to ARV access was its exorbitant cost that only a tiny wealthy minority could pay. An exception to this paradigm was Brazil, whose universal healthcare system compelled the government to provide access to ARV treatment for PLWHA. The first ARVs cost over $\$ 10,000$ per year per person (UN Millennium Project, 2005, p.77).

Patent-holding pharmaceutical companies have argued that the high cost of ARVs has been necessary to fund its research and innovation (Bartlett \& Spar, 2005 ; Wells \& Rabe, 2005). Invoking the 1995 Agreement of Trade Related Aspects of Intellectual Property Rights (TRIPS), pharmaceutical companies have demanded the strict protection of its patents in developing countries at the World Trade Organization (WTO) (Wells \& Rabe, 2005). In this context, middle income countries like Brazil, South Africa and India, which have threatened generic ARV production if brand prices did not lower, have been the targets of complaints at the WTO from the developed countries where ARV producers are based (Goozner, 1999). In order to strike a balance between the healthcare needs of the developing world and intellectual property (IP) rights, the 2001 Doha Declaration incorporated flexibilities and safeguards in TRIPS. These legislative buffers allow national authorities to determine the grounds on which compulsory licenses can be issued for the production and purchase of patented items (WTO, 2011).

Drug therapy has since significantly decreased in price. In December of 2009, an estimated 5.2 million PLWHA in lower and middle income countries were receiving ARVs (UNAIDS, 2010, p. 96). This has been the result of numerous factors: differentiated pricing schemes from research based manufacturers, generic competition, the incorporation of 
health safeguards in IP legislation and the aggressive lobbying by developing countries and advocacy groups (UN Millennium Project, 2005, p. 79).

Albeit the expansion of access to ARVs worldwide, 10 million PLWHA in the developing world, who are eligible for treatment, still do not have access to ARVs (UNAIDS, 2010, p. 95). Advocacy groups from the developing world continue to hold IP rights partially responsible for this lack of access and have, thus, continued to lobby for more exceptions and flexibilities to IP legislation concerning essential medicines. They are critical that developing countries have rarely invoked TRIPS safeguard mechanisms and are concerned with the stricter IP protection that comes with bilateral and regional trade agreements with high-income countries (Muzaka, 2009, pp. 1343-1361).

\section{2 "SOUTH-SOUTH" COOPERATION AMONG AIDS-RELATED NGOS}

During the late 1990s, the fight for access to ARVs resulted in the mobilization of organized advocacy groups and NGOs in the "Global South." New NGOs and new divisions of old NGOs were created with the aim to prevent IP rights from being a barrier to the access of essential medicines. These groups were comprised of lawyers, other authorities of the law and advocates of PLWHA. Coordinators of the Brazilian Interdisciplinary Association of AIDS (ABIA) also attribute this phenomenon to the "abuses [that] were being practiced in many countries by international pharmaceutical companies with the corroboration of weak governments that did not prioritize the lives of their citizens" (ABIA, 2009, p. 10). As such, the scope of these civil society groups had to include not just individual pharmaceutical companies and domestic and international IP regimes, but also blatant government corruption unique to the developing world.

These organizations attempt to minimize the negative ramifications of the patent system at both the national and international level. At the national level, NGO activities include (but are not limited to): 
- filing legal and administrative actions against the patentability of certain essential medicines

- lobbying the government to develop national R\&D facilities to produce affordable drugs

- disseminating information about the social impact of IP trade agreements in order to shape and mobilize public opinion.

At the international level, NGO activities include but are not limited to:

- lobbying their governments to invoke TRIPS flexibilities and safeguards to expand access to ARVs

- monitoring and participating in international forums that discuss the topic of IP rights and/or access to medicines

- initiating and strengthening North-South and South-South cooperation to promote information sharing and joint actions

\subsubsection{Factors that encourage South-South Cooperation}

For various reasons, South-South cooperation has become a priority for many of these advocacy groups. The term "South-South cooperation" describes the exchange of resources, technology and knowledge between developing countries. This term is derived from the "North-South divide" which describes the political and socioeconomic division between developed and developing countries, respectively the "North" and "South" countries. This term further emphasizes the "on-top" nature of the "North" in that it has a disproportional amount of the world's wealth.

To identify factors for the trend towards South-South cooperation and knowledge sharing between AIDS NGOs, it is important to firstly consider the current trend towards political and economic South-South cooperation. The BRICS, the most well-known example of this phenomenon, is an international political organization of emerging countries (Brazil, Russia, India, China and South Africa), which seeks to increase its members' political and economic collaboration. The combined political and economic clout of these nations and other developing countries is significant 
- and at times, pivotal- especially in international forums like the WTO, where each member state has a vote of equal weight. Southern AIDSrelated civil society groups have it in their interest to coordinate lobbying efforts on their distinct governments to protect safeguards and flexibilities in the TRIPS Agreement (Muzaka, 2009, pp. 1343-1361).

A second factor to encourage South-South cooperation is the relative inexperience that developing countries have had with IP legislation and its enforcement. Many developing countries are young democracies, which had lax or no IP enforcement prior to TRIPS (Muzaka, 2009, pp. 1343-1361). Upon admission to the WTO, they have had to hastily incorporate a strict and unfamiliar IP regime to their legislations and are slowly gaining experience as how to balance IP and public health responsibilities. AIDS-related NGOs from the South seek to learn from the experience of their counterparts to effectively secure, within the boundaries of TRIPS, access to medicines for PLWHA.

Thirdly, AIDS' distinct intensity in developing countries encourages South-South cooperation among NGOs. A treatable disease, AIDS particularly proliferates and becomes life-threatening where preventative and therapeutic treatments are unavailable - chiefly, in poor countries. This shared experience of a "lack" to effectively tackle AIDS makes the case for universal access to ARVs more urgent for the South. Members of these NGOs, many who are motivated by a family member or a loved one afflicted with AIDS, acutely feel this urgency and seek empathy and wisdom from members of NGOs in similar situations. South-South cooperation among these NGOs, thus, demonstrates a transfer of both intellectual and emotional knowledge as to how to increase access to ARVs.

A fourth factor for fostering South-South cooperation between AIDSrelated NGOs is the transnational nature of pharmaceutical companies. Developing countries where pharmaceutical companies are submitting patent applications can share notes concerning the argumentation and proof of the novelty and inventive step of a pharmaceutical's R\&D. Furthermore, developing countries can band together to demand price reductions from 
pharmaceutical companies or face a compulsory license, which compels the generic production of a drug by a domestic company.

As described, the globalized nature of government, business and the AIDS epidemic support South-South cooperation among AIDS-related NGOs in the area of IP rights in order to secure access to AIDS medicines. "South-south cooperation is key in tackling the issue of intellectual property and access to medicines, since the changes to the legal framework in the field of intellectual property have had a far more profound impact on countries in the southern hemisphere" (Muzaka, 2009, pp. 1343-1361). Developing countries had to hastily implement unfamiliar IP legislation into their laws, whereas most developed countries were already accustomed to modern IP and patent systems. South-South cooperation among civil society, thus, should aim to facilitate the management and transfer of knowledge to secure access to ARVs in the context of the modern IP system. Such knowledge includes experiences in but not limited to: legal argumentation, research methodologies, organizational structures and behavior, methods of civil society mobilization, lobbying methods, technological knowledge, South-South and North-South collaborative experiences.

\section{BIBLIOGRAPHY}

\subsection{LITERATURE ON KNOWLEDGE MANAGEMENT AND NON-PROFITS}

The American Oxford Dictionary (n.d.) defines 'knowledge' as the "facts, information, and skills acquired by a person through experience or education; the theoretical or practical understanding of a subject." A more profound definition, knowledge is a "justified personal belief that increases an individual's capacity to take effective action" (Alavi and Leider, 2001, p. 107). Knowledge is not the same as information but they are related, in that having access to information is necessary for understanding or knowledge to occur (Sharrat \& Usoro, 2003). Knowledge bifurcates into 
explicit and implicit knowledge (Polyani, 1964). Explicit knowledge is "knowing about," which can be easily expressed and shared through manuals, data, etc. Implicit knowledge, on the other hand, is "knowing how," which is difficult to share since its scope includes hunches, insights and intuitions (Connell et al., 2003). Tacit knowledge needs to be translated into explicit knowledge in order for knowledge transfer and interchange to occur (Connell et al., 2003). The translation of tacit knowledge into explicit knowledge within the individual and the transfer of explicit knowledge between individuals or organizations are the two fundamental actions of knowledge management theory (Hurley, 2005).

Knowledge management is "the process by which an organization creates, captures, acquires, and uses knowledge to support and improve the performance of the organization" (Kinney, 1998, p. 2). Knowledge management is then comprised of both knowledge transfer and knowledge creation activities, and a knowledge intensive organization prioritizes both. Knowledge intensive organizations work in intellectually demanding areas and are staffed in greater part by highly educated individuals. Examples of knowledge intensive organizations are law and accounting firms, research centers, laboratories, etc. In recent literature, philanthropic institutions are also identified as knowledge intensive institutions (Hurley \& Green, 2005; Capozzi, Lowell \& Silverman, 2003). Accordingly, AIDS-related NGOs are knowledge intensive organizations since they employ educated individuals such as physicians, psychologists, lawyers, health-care workers and educators (Hurley \& Green, 2005).

Literature on knowledge management practices tend to focus on forprofit organizations due to the intense pressure from shareholders and customers to adopt knowledge management practices to respectively increase share price and decrease product price. Demand for knowledge intensive for-profits is strong. Considering the increased globalization of business and the subsequent proliferation of franchises, companies seek to replicate or customize successful knowledge management practices in different localities (Hurley \& Green, 2005). 
There is a lack of literature, however, on knowledge management practices in non-profits. This is due to a lack of demand for knowledge management practices from the non-profit community (Hurley and Green, 2005). This lack of demand has translated into the non-profit sector's failure to replicate successful programs. They "...lack the critical processes and knowledge needed to help them develop, evaluate, document, and share successful programs" (Hurley \& Green, 2005, p. 2). This failure is further attributed to spending...

...large amounts of time, funds and imagination...reinventing the wheel, while the potential of programs that have already proven their effectiveness remains sadly underdeveloped. This, in many instances represents a substantial loss to society overall. The objective is to replicate the successful program's results, not to recreate every one of its features (Bradach, 2003, p. 19).

Although NGOs largely employ highly skilled capital, they are not building off the experiences of their counterparts and are ineffective in deploying their own untested methodologies. This results in the fallowness of an NGO's most important resource: human capital (Bradach, 2003).

In response to the inadequate knowledge management practices of the non-profit community, NGOs should take a "within" and "between" approach to knowledge management (Hurley \& Green, 2005). The within approach requires the transformation of an individual organizational culture, and the between approach emphasizes the potential knowledge transfer and leverage in the linkages between similar non-profits (Hurley \& Green, 2005).

Non-profits must thoroughly examine their organizational culture to determine the barriers to communication within and between NGOs (Alavi \& Leidner, 2001). 'Knowledge hoarding' is a significant example of a barrier to productiveness (Yang, 2004; Brand, 1998; Hickens, 1999). For example, hoarding is rife in institutions that promote individuals who possess the most knowledge rather than those who share the most knowledge (Hayduk, 
1998). There is also a need for shorter lines of communication that facilitate transparency between employees and management or between non-profits, as this allows an organization to quickly adapt to a given situation, accelerating effective decision-making (Sharratt \& Usoro, 2003).

\subsection{LITERATURE ON COLLABORATION}

For the purposes of this paper, the effects of the 'between approach' or the 'collaborative approach' is more relevant in evaluating South-South non-profit collaboration. Collaboration is "a cooperative, interorganizational relationship that is negotiated in an ongoing communicative process, and which relies on neither market or hierarchal mechanisms of control" (Hardy et al., 2003) Academic literature tends to categorize collaboration on their effects (Powell, Koput \& Smith-Doerr, 1996). In the area of knowledge management, non-profit collaborations are described to have strategic effects, knowledge creation effects and political effects (Hardy et al., 2003).

Strategy literature perceives collaboration as a means to having access to resources and skills that would not be available internally (Afuah, 2000; Dyer \& Singh, 1998; Gulati et al., 2000a; Hamel, 1991; Hamel et al., 1989; Hennart, 1988; Teece, 1986; Williamson, 1991). Such collaboration includes but is not limited to knowledge transfer of technology, IP and assets (Dyer \& Sing, 1998; Hamel et al. 1991). These resources are perceived as necessary to be effective in reaching organizational goals and distinct enough to maintain sufficient demand (Powell, Koput \& SmithDoerr, 1996). Domain Theory holds a similar position, proposing that collaborations result in the convergence of resources to produce solutions to social dilemmas (Gray 1989; Trist 1983). Solutions should strive to be distinct. Distinctiveness is the extent to which an asset or skill is able to distinguish an organization's activities from its competitors. Distinctiveness should be difficult to imitate (Prahalad \& Hamel 1990; Wernerfelt 1984).

A second approach to collaboration is one of innovation and learning. Literature in this field asserts that collaboration can result in the 
creation of new knowledge and new capabilities that neither organization possessed before the collaboration (Gulati, 1999; Powell, 1990; Powell et al., 1996). This goes one step beyond the strategic transfer of knowledge. From a philosophical perspective, knowledge is the extension of the community, not a possession belonging to individuals (Brown \& Duguid, 1991; Hendry, 1996; Larsson et al., 1998; Powell and Brantley, 1992).

Knowledge creation occurs in the context of a community, one that is fluid and evolving rather than tightly bound or static . . . Sources of innovation do not reside exclusively inside firms; instead, they are commonly found in the interstices between firms, universities, research laboratories, suppliers and customers (Powell et al., 1996, p. 121).

As such, collaboration is not a way to compensate for a lack of knowledge, but rather as a way to generate new, relevant capabilities.

The third effect of collaboration stems from research in the area of networks and social capital. Collaboration, in this sense, can transform the structure of inter-organizational relationships; those organizations that act jointly take up a more central position in their network (e.g Dyer, 1996; Gulati, 1998; Nohria \& Eccles, 1992; Wasserman \& Galaskiewicz, 1994; Bourdieu, 1993; Laclau \& Mouffe, 1985; Nahapiet \& Ghoshal, 1998). Having a more center status would result in greater influence over the periphery organizations (e.g., Burt, 1992; Hardy \& Phillips, 1998; Knights et al., 1993; Warren et al., 1974). Centrality is consequential because organizational power is not so much the result of direct control over assets and capabilities, but rather "the set of resources that actors [can] mobilize through their existing set of social relationships" (Galaskiewicz, 1979, p.151). "Within inter-organizational networks, nodal points exist from where actors not only control the flow of critical resources, and especially information, but also shape the meanings attached to those resources" (Hardy et al., 2003, p. 7). The political influence that collaborations can generate are, thus, significant. 


\section{COLLABORATORS}

\subsection{THE BRAZILIAN INTERDISCIPLINARY ASSOCIATION OF AIDS}

Founded in 1987, the Brazilian Interdisciplinary Association of AIDS (ABIA) is the largest non-governmental AIDS organization in Brazil and, of its many activities, is dedicated to securing assistance and treatment for PLWHA. In this regard, ABIA is known for playing an instrumental role in evaluating and formulating public policy, as well as assisted in the development of educative and preventative programs to prevent the spread of AIDS. At its headquarters in the Center of Rio de Janeiro, ABIA has developed one of the biggest library collections on STDS/HIV/AIDS in the country. ABIA carries out many of its informative, preventative and treatment programs jointly with the local, state and federal government (ABIA, n.d.).

ABIA has coordinated legal efforts with the Working Group of Intellectual Property Rights (GTPI) of the Brazilian Network for the Integration of Peoples (REPRIB). REPRIB is an umbrella network of NGOs, social movements, labor unions and professional and academic associations that are engaged in the policymaking surrounding regional integration and trade. Members and organizations of REPRIB are committed to sustainable development and are against trade and financial liberalization that have a negative effect on society, culture and the environment. Given the fierce debate encompassing international IP rights and their impact on access to medicines, members of REPRIB founded the Working Group of Intellectual Property Rights (GTPI) to specifically address IP and its implications on Brazilian society (GTPI, n.d.).

Since its creation in 2001, GTPI has coordinated efforts with the Brazilian Interdisciplinary AIDS Association (ABIA) in order to minimize the negative impact of the Brazilian and international patent system. Strategies are of a legal, collaborative, social and networking nature in order to identify ways to increase access to essential medicines for PLWHA. In 
particular, GTPI and ABIA seek collaborations with similar organizations from the South in order to facilitate knowledge transfer and joint actions (GTPI, n.d).

\subsection{THE LAWYERS COLLECTIVE}

Founded in 1981, the Lawyers Collective is one of the most wellknown public interest advocacy groups in India that specializes in the area of human rights, legal aid and litigation. Of particular relevance to this paper is its HIV/AIDS team, which is committed to protecting and promoting the rights of PLWHA. The Lawyers Collective has designated a team that solely focuses on securing access to medicines. Since 2001, it has focused on IP rights in order to maintain, among other reasons, India's position as the primary source of generic medicines for PLWHA in the developing world (The Lawyers Collective, n.d.).

\subsection{SAHARA}

Founded in 1978, SAHARA AALHAD, the Center of Residential Care and Rehabilitation (SAHARA), started off as a transitional therapeutic community in New Delhi offering services to people who suffer from substance abuse. Since then, it has transformed into a non-governmental organization that also provides services to PLWHA. SAHARA is committed to empowering people and communities through the dissemination of information about AIDS and PLWHA. Run mainly by PLWHA and former substance abusers, SAHARA is well-know domestically and internationally for its work in providing and securing access to treatment for PLWHA (SAHARA, n.d.).

\section{DATA COLLECTION AND METHODOLOGY}


This study was first developed out of participant observation research from March to November of 2009. It was then supplemented with archival research on the following topics:

- AIDS in developing world

- IP rights and access to medicines

- South-South cooperation

- Knowledge management and the non-profit sector

- Knowledge management and the effects of collaboration

Literature ranged from relevant books, articles off of J-Stor and Ebsco, organizational memos, newsletters, reports, meeting minutes, funding proposals, year-end reports and other material. Informal and formal interviews with contacts, who include the coordinators of ABIA, the in-house lawyers and relevant contacts from partner organizations, provided information on the aims, nature and outcomes of the collaborations of this study. Access to these contacts were facilitated by the author's position as a volunteer co-worker at ABIA and her logistical work on the IAS satellite event. Interviews were conducted in English, Portuguese and Spanish; interviews in the latter two languages were translated by the writer.

The data analysis for this article consisted of three stages: (1) develop a chronological description of the collaboration; (2) describe the nature of the South-South collaboration via two dimensions involvement and embeddedness; (3) identify the types of effects resulting from the collaboration and test propositions of the relationship between the dimensions and collaborative effects posited in Resources, Knowledge and Influence: the Organizational Effects of Interorganizational Collaboration (Hardy et al., 2003).

In the first stage of data analysis, the author developed a chronological description of the collaboration using archival research, interviews and participant observation. The chronological description describes the conceptualization and development of the collaboration, describing when it came about, who was involved, where meetings took 
place (in person or virtually) and major outcomes. The author confirmed that she had understood events correctly by coordinating the descriptions with contacts at ABIA. More pithy and succinct descriptions were created from these summaries.

During the second stage of data analysis, the author applied a codification methodology (Hardy et al., 2003) which describes the nature or characteristics of collaboration to the degree of two dimensions involvement and embeddedness. Involvement refers to the internal dynamic between organizations or the way these organizations interacted with each other. In this sense, collaborations are classified by their depth (deep or shallow), structure (transaction, partnership or representation) and bilateral information flows (unidirectional, bi-directional, multi-directional). Collaboration is categorized as low, medium or high involvement. Embeddedness refers to the degree at which the collaboration affects interorganizational relationships. In that regard, collaborations are classified by their interactions with third parties, representation and multi-directional information flows. The author chose to use these characteristics because the results assist in discerning patterns linking the nature and effects of collaboration.

In the concluding stage of data analysis, the author determined the types of effects - strategic, knowledge creation or political - that resulted from the collaboration and then compared the effects with the aims of the joint action. A list of the effects of the collaboration were provided to me via archival research, interviews and participant observation. Categorizing the types and the degree of the effects allowed the author to measure the involvement and embeddedness of the collaboration. Furthermore, the author tested these results against propositions of the relationship between involvement and embeddedness and the collaborative effects posited (Hardy et al., 2003) to determine the practicality of their methodology in predicting the strategic effects of a collaboration.

\section{DISCUSSION AND DATA ANALYSIS}




\subsection{CHRONOLOGICAL DESCRIPTION OF COLLABORATION}

In August of 2006, ABIA/GTPI sent its in-house lawyer to give a presentation on Brazil's production capabilities in producing second-line ARVs at the International AIDS Society (IAS) Conference in Toronto. The in-house lawyer had been working at ABIA for less than a year and had little exposure to AIDS-related international activities. She was walking into her allotted conference room accompanied by an activist from Oxfam, when she happened upon an Indian IP lawyer from the Lawyers Collective, an Indian public interest legal group. He was sat under one the myriad of posters announcing her presentation, emailing her via mobile to propose a meeting. They struck up a conversation, thus initiating dialogue about the experience that their respective organizations had in the area of IP rights and access to medicines (Reis, personal communication, December 4, 2011).

ABIA and GTPI had little experience in submitting pre-grant oppositions due to the lack of technical capabilities it had in evaluating patent applications. The Lawyers Collective, on the other hand, had already submitted three pre-grant oppositions, one of which was against the patent application of tenofovir, a second-line essential ARV in the treatment against HIV/AIDS. In an interview (Reis, personal communication, July 5, 2009), ABIA's in-house lawyer explains that the actions of the Lawyers Collective inspired their Brazilian counterpart to take similar action against tenofovir, since its producer Gilead had also submitted a patent application to Brazil. In the eyes of PLWHA, tenofovir should not be granted a patent because of its lack of an inventive step; tenofovir has been the consequence of combining a known salt with a known drug at the time.

The lawyer and the coordinators of ABIA and members of GTPI believed that they could learn much from the Lawyers Collective's experience in the area of pre-grant oppositions and committed to dialogue with their Indian counterpart after the IAS Conference in Toronto. Of particular importance to ABIA and GTPI was the Lawyers Collective's argumentation in pre-grant oppositions. This argumentation required 
extensive technical knowledge that ABIA and affiliate Brazilian organizations were only beginning to develop. The lack of enforcement of IP legislation in Brazil prior to TRIPS had resulted in an underdeveloped knowledge in this area (Reis, personal communication, December 4, 2011; Terto, personal communication, June 10, 2009).

Dialogue and the exchange of knowledge and information was at first directed towards the enhancement of ABIA's IP expertise. Communication was done solely via email and Skype calls. The direction of knowledge flows, however, became increasingly bilateral as the Lawyers Collective began to realize the similarities between Brazil's and India's bureaucratic systems. Legal argumentation developed by their Brazilian counterpart would contribute to future patent oppositions in India (Reis, personal communication, December 4, 2011).

In December of 2006, ABIA along with other organizations of Brazilian civil society submitted a pre-grant opposition against tenofovir's application in Brazil. ABIA acknowledges that the Lawyers Collective's leadership in patent oppositions was instrumental in the development of the argumentation and language of this pre-grant opposition (Reis, personal communication, December 4, 2011) (For timeline of tenofovir in Brazil and India, see chart 2).

Thereafter, ABIA and the Lawyers Collective commenced searching for South-South opportunities of legal collaboration in the area of patent oppositions. Having been brought together by tenofovir, it seemed the most relevant and practical choice as a guinea pig. Furthermore, it was well-known at the time that India's decision in regards to the patentability of tenofovir would have significant consequences on access to the drug in the developing world (Reis, personal communication, December 4, 2011). India was the largest producer of generic pharmaceutical medicines in the developing world (Lawyers Collective, n.d.). An essential medicine in second-line ARVs, tenofovir was already being produced as a generic in India; Brazil still lacked the capabilities to produce its own generic version of tenofovir. Brazilian activists reasoned that a tenofovir patent in India 
would preclude Brazil from importing tenofovir or its constituent elements from Indian generic companies due to the resulting increase in prices for the proprietary version. At the time of the opposition, tenofovir cost US $\$ 1,387$ per patient per year in Brazil, whereas in India, the generic version of tenofovir cost only US $\$ 158$ (Anderson, 2008).

The Lawyers Collective and ABIA gradually identified an opportunity for South-South collaboration: ABIA could submit a pre-grant opposition against the tenofovir patent application jointly with an Indian NGO in India since the law allowed for a foreign organization to do so. The collaboration (Reis, personal communication, December 4, 2011) had four main objectives:

1) to put more pressure on the Indian government to deny the patent application

2) to put pressure on Gilead to drop its patent objectives for tenofovir in India and Brazil

3) to raise awareness of the grave consequence of a tenofovir patent in India on not just India but the rest of the developing world

4) to set an example of South-South cooperation that other NGOs could replicate

Unable to file a second opposition to tenofovir, one of the organizations that the Lawyers Collective represented, SAHARA, volunteered to submit an opposition jointly with ABIA. Talks over the development of the opposition were, however, between the Lawyers Collective and ABIA (Reis, personal communication, December 4, 2011).

ABIA and the Lawyers Collective had no precedent of a similar case; a foreign non-profit organization had never submitted a pre-grant opposition in India. Thus, ABIA and the Lawyers Collective worked closely on developing the argumentation, language and press releases for the opposition. In total, it took three months to write up the joint opposition.

On June $26^{\text {th }} 2008$, ABIA and SAHARA submitted the pre-grant opposition to the patent application of tenofovir. No representative from 
ABIA was present at the opposition's submission; ABIA was represented by SAHARA and Lawyers Collective. As this sort of joint action was unprecedented, it and its implications were widely discussed in the media within the following months.

Since the submission of the opposition, ABIA and the Lawyers Collective have worked together on the development of legal argumentation for oppositions within their respective countries and on the translations of several projects. They have also separately and jointly presented the tenofovir collaboration as a case study at various AIDS-related functions. In 2009, ABIA hosted a satellite event on South-South cooperation in the area of IP rights and access to ARVs at the annual International AIDS Society Conference in South Africa. The Lawyers Collective and ABIA both discussed their collaboration on the tenofovir opposition in India at the Conference.

In 2009, tenofovir's patent application in both India and Brazil was denied. Furthermore, the generic price of tenofovir has greatly lowered, benefiting the PLWHA community in both India and Brazil (see table 3). This has ensured the sustainability of the universal treatment program for PLWHA in Brazil.

\begin{tabular}{|c|c|}
\hline 2002 & - Gilead files patent application of tenofovir in India and Brazil \\
\hline 2005 & - Generic production of tenofovir starts in India \\
\hline 2006 & $\begin{array}{l}\text { - Gilead signs voluntary licensing agreements (VLs) with all but } \\
\text { one of the Indian generic companies (Cipla) that can produce } \\
\text { the generic version of tenofovir. VLs limit exportation. Brazil, } \\
\text { China and Sri Lanka are excluded from exportation list. } \\
\text { - Indian civil society organizations (including the Lawyers } \\
\text { Collective) submit pre-grant oppositions to tenofovir in India } \\
\text { - Brazilian civil society groups (including ABIA) file pre-grant } \\
\text { oppositions to the patent application of tenofovir in India }\end{array}$ \\
\hline 2008 & $\begin{array}{l}\text { - Tenofovir becomes a medicine of public interest in Brazil } \\
\text { - ABIA and SAHARA file pre-grant oppositions to the patent } \\
\text { application of tenofovir in India } \\
\text { - Brazilian Patent Office publish patent rejection of tenofovir }\end{array}$ \\
\hline 2009 & $\begin{array}{l}\text { - Brazilian Patent Office publishes final patent rejection of } \\
\text { tenofovir }\end{array}$ \\
\hline
\end{tabular}




\begin{tabular}{|l|l|}
\hline & $\begin{array}{l}\text { Several patent applications, relating to tenofovir are rejected } \\
\text { by the Indian Patent Office }\end{array}$ \\
\hline 2010 & $\begin{array}{l}\text { Gilead submits a legal challenge to the tenofovir patent } \\
\text { rejection in Brazil }\end{array}$ \\
\hline 2011 & $\begin{array}{l}\text { Gilead submits a divisional patent application for tenofovir in } \\
\text { Brazil }\end{array}$ \\
\hline $\begin{array}{l}\text { Brazil begins local production of tenofovir through partnership } \\
\text { between public and private manufacturers. } \\
\text { Divisional patent of tenofovir is rejected in Brazil }\end{array}$ \\
\hline
\end{tabular}

\section{Chart 2: Timeline of Tenofovir in India and Brazil}

Source: adapted from Médecins Sans Frontières, 2011, p. 48

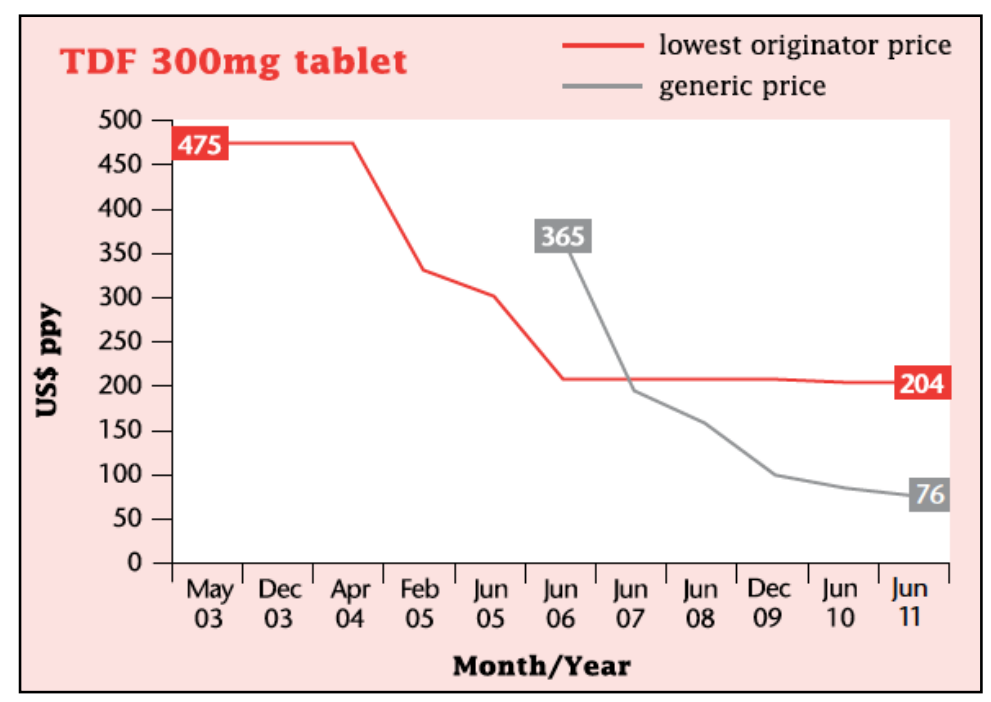

\section{Graph 1: Evolution of Tenofovir's Lowest Price for Developing Countries since 2003 \\ Source: Médecins Sans Frontières, 2011, p. 49}

\subsection{NATURE OF COLLABORATION}

In order to evaluate the nature of the collaboration, the author has applied a codification methodology developed in Resources, Knowledge and Influence: the Organizational Effects of Interorganizational Collaboration (Hardy et al., 2003), which describes the nature of the collaboration in terms of two dimensions involvement and embeddedness. Involvement refers to the internal dynamic between organizations or the way these organizations interact with each other. In this sense, collaborations are classified by their (1) depth (deep or shallow), (2) structure (transaction, 
partnership or representation) and (3) bilateral information flows (unidirectional, bi-directional, multi-directional). Collaboration is categorized as low, medium or high involvement. Embeddedness refers to the degree at which the collaboration affects inter-organizational relationships. In that regard, collaborations are classified by their interactions with third parties, representation and multi-directional information flows. The author chose to use these characteristics because the results assist in discerning patterns linking the nature and effects of collaboration.

The degree of involvement and embeddedness of this collaboration are based on three other dimensions, (1) patterns of interaction, (2) structure and (3) patterns of information flow, that differentiate the collaboration between the Lawyers Collective and ABIA. SAHARA's participation is considered a result of their collaboration.

Firstly, the collaboration is measured by the patterns of interactions among collaborating organizations. Patterns are evaluated by their depth and scope. In regards to depth, a shallow interaction would characterize collaboration only between selected personnel and its counterpart. A deep collaboration is one, in which interactions extend beyond a specific group of personnel. In this case, the collaboration would be described as a shallow interaction because interaction surrounding the development of the collaboration did not extend beyond the lawyers from ABIA and the Lawyers Collective. In fact, ABIA talked solely with the Lawyers Collective during the development of the opposition and had not talked with other personnel from the Lawyers Collective or SAHARA until the pre-grant opposition's submission at the Indian Patent Office.

The scope of interactions is defined as either narrow or broad. A narrow interaction would describe ABIA and the Lawyers Collective if it had only collaborated between themselves. A broad interaction would describe their collaboration if they interacted with third parties. In this case, ABIA and the Lawyers Collective interacted with SAHARA in the development of 
this collaboration, taking it on as a third partner. Thus, the collaboration could be described as having a broad scope.

Secondly, the collaboration is measured by the structure of the new collaboration. The structure comes in three forms: transactions, partnerships and representation. A transaction describes a collaboration that did not result in a new coalition, but rather in the strategic transfer of resources to one of the collaborating organizations. A partnership characterizes a collaboration that engenders a new coalition in which ABIA and the Lawyers Collective work together to carry out a particular objective. A representation describes a collaboration that results in a new coalition, in which the collaborating organizations represent each other's interests to outside parties. In this case, we see that the collaboration between ABIA and the Lawyers Collective transformed from a transaction to a partnership when they decided to work together in submitting a pre-grant opposition to the patent application of tenofovir in India. Furthermore, it can also be described as a representation due to the Lawyer Collective's position as a representative of SAHARA, a separate organization, in the development of the pre-grant opposition. The Lawyers Collective also represented ABIA when the pre-grant opposition was submitted to the Indian Patent Office. Therefore the structure is both a partnership and a representation.

Thirdly, the collaboration is evaluated by its patterns of information flow, which are categorized as: unidirectional, bi-directional and multidirectional. Unidirectional flows of information occur when only one of the collaborating organizations learns from the other. Bi-directional flows of information occur when both collaborating partners learn from each other. Multi-directional flows of information occur when collaborating organizations and third parties learn from each other. In this case, ABIA's collaboration with the Lawyers Collective has multi-directional flows of information because the collaborating organizations ABIA and the Lawyers Collective learned from each other and third parties like SAHARA and other AIDSrelated NGOs have learned from this collaboration. Although the Lawyers Collective at first acted as a mentor to ABIA and the flows of information 
were unidirectional, their collaboration increasingly became bi-directional and then multi-directional when SAHARA joined in on the collaboration. The impact of this collaboration extends beyond these three organizations: ABIA and Lawyers Collective have both separately and jointly given presentations and written about this collaboration and the legal argumentation used in developing the pre-grant opposition for the NGO community. Before this collaboration, many health- and IP-related NGOs did not know that such a collaboration could exist due to the peculiarities of the legal framework of each country. Furthermore, it shed lights on the potential of South-South Collaboration.

A re-cap of the dimensions that are used to evaluate the degree of involvement and embeddedness of the collaboration between ABIA and the Lawyers Collective are provided in the table below.

\begin{tabular}{|c|c|c|}
\hline $\begin{array}{l}\text { Patterns of } \\
\text { Interaction }\end{array}$ & Structure & $\begin{array}{l}\text { Patterns of } \\
\text { Information Flow }\end{array}$ \\
\hline $\begin{array}{l}\text { Shallow, broad } \\
\text {-internal dynamics of } \\
\text { collaboration did not } \\
\text { extend beyond the } \\
\text { lawyers of ABIA and } \\
\text { Lawyers Collective } \\
\text {-collaboration } \\
\text { interacted with third } \\
\text { party SAHARA }\end{array}$ & $\begin{array}{l}\text { Partnership, } \\
\text { Representation } \\
\text {-new coalition with } \\
\text { distinct objective: pre- } \\
\text { grant opposition to } \\
\text { tenofovir in India } \\
\text { submitted jointly with } \\
\text { SAHARA } \\
\text {-Lawyers Collective } \\
\text { acted as representative } \\
\text { of third party SAHARA }\end{array}$ & $\begin{array}{l}\text { Multi-directional } \\
\text {-collaborating } \\
\text { organizations and third } \\
\text { parties (SAHARA and } \\
\text { other related-NGOs) } \\
\text { learned from this } \\
\text { collaboration }\end{array}$ \\
\hline
\end{tabular}


The aggregate dimensions of involvement and embeddedness respectively describe internal and external dynamics of the collaboration. Involvement refers to the way that collaborating organizations interact with each other. Collaborations with (1) deep interactions, (2) partnerships and at least (3) bilateral information flows as described as having a high level of involvement. Accordingly, the collaboration between ABIA and Lawyers Collective would be classified as having medium involvement due to its shallow interactions, partnership structure and multi-directional information flows.

Embeddedness, on the other hand, describes the way that collaborating organizations interact with organizations outside its relationship. Thus, this aggregate dimension concerns the broader interorganizational network. Collaborations with (1) broad interactions, (2), a representation structure and (3) multi-directional information flows are deeply embedded within the inter-organizational network. Since the collaboration between ABIA and Lawyers Collective is categorized as being all three, it would be classified as having deep embeddedness.

\subsection{COLLABORATION EFFECTS ON ABIA}

In Resources, Knowledge and Influence: the Organizational Effects of Interorganizational Collaboration (Hardy et al., 2003) three propositions are introduced regarding the effects of collaborations:

- Proposition 1: Collaborations that have high levels of involvement will be positively associated with the acquisition of distinctive resources

- Proposition 2: Collaborations that have high levels of involvement and high levels of embeddedness will be positively associated with the creation of knowledge

- Proposition 3: Collaborations that are highly embedded will be positively associated with an increase in influence. 
The author will appraise these propositions while examining the levels of strategic, knowledge creation and political effects of the case study collaboration on ABIA.

\subsubsection{Strategic Effects}

As pointed out earlier, strategic effects are those that permit organizations to secure resources or capabilities that they would otherwise not be able to develop internally. In this sense, only distinctive resources or capabilities - ones that differentiate an organization from its counterpart - are considered strategic. The collaboration between ABIA and the Lawyers Collective was highly strategic for ABIA because of the significant knowledge transfer that was directed from the Lawyers Collective to ABIA. As written before, the Lawyers Collective was an organization experienced in submitting pre-grant oppositions, whereas ABIA was not. In collaborating together, ABIA employed some of the Lawyers Collective's legal argumentation and language in writing up an opposition to the patent application of tenofovir in Brazil. ABIA acquired techniques that accelerated the scrutiny of the patent application from the Lawyers Collective. Furthermore, ABIA was able to enhance its network of Southern contacts via the Lawyers Collective, which introduced ABIA to various AIDS-related Indian organizations.

In that regard, ABIA demonstrates that first proposition put forth is true (Hardy et al., 2003): collaborations that have high levels of involvement will be positively associated with the acquisition of distinctive resources. Although the collaboration between the Lawyers Collective and ABIA was characterized as having medium levels of involvement, the acquisition of distinctive resources is still prevalent.

\subsubsection{Knowledge Creation Effects}

Before evaluating whether knowledge creation was one of the effects of the collaboration between the Lawyers Collective and ABIA, it is 
necessary to examine the difference between knowledge and information. As discussed within the literature review, access to information is necessary for understanding or knowledge to occur (Sharrat \& Usoro, 2003). The author would argue that although information on the legal mechanism surrounding foreign pre-grant oppositions was available to the public, patient organizations had no practical knowledge in invoking it because of a lack of precedent. In that sense, there was a lack of knowledge regarding the effectiveness of its employment and the strategies needed to effectively employ it.

In deciding to invoke this legal mechanism, ABIA and the Lawyers Collective, however developed new practical knowledge in that regard. They had to develop a strategy prior to submitting the opposition to garner legal and morale support from other AIDS-related organizations and the general public. ABIA and the Lawyers Collective were wary that a pre-grant opposition would be perceived as a "foreign intrusion" (Reis, personal communication, December 4, 2011) and sought public support from other AIDS-related Indian organizations, chiefly SAHARA. They also implemented an intensive campaign to disseminate information about the tenofovir patent application and its importance for PLWHA in the developing world. "The campaign and support from Indian AIDS-related NGOs resulted in a growing credibility for the pre-grant opposition to tenofovir among Indians" (Reis, personal communication, December 4, 2011).

Secondly, the collaboration between ABIA and Lawyers Collective shed light on the potential of free or economical communication devices like Skype and the Internet in supporting South-South collaboration. Technological advances and the diminishing price for its employment have facilitated collaboration between Southern organizations that have limited budgets and resources. Solely using email and Skype, ABIA and the Lawyers Collective were able to effectively communicate and draft up a patent opposition together. Furthermore, this made ABIA's presence in India inconsequential. This is demonstrated when SAHARA and the Lawyers 
Collective represented ABIA when submitting the pre-grant opposition to tenofovir at the Indian Patent Office.

In the literature review, knowledge creation is said to occur in the context of the community; it does not occur within an organization but between it and another organization (Powell et al., 1996). Knowledge creation can include the development of innovative practices (Hardy et al., 2003). In that regard, the collaboration between ABIA and the Lawyers Collective created new practical knowledge surrounding strategies in the area of IP rights and health and South-South cooperation.

Proposition 2 states that collaborations that have high levels of involvement and high levels of embeddedness will be positively associated with the creation of knowledge. This proposition is confirmed, in that the collaboration between Lawyers Collective and ABIA manifested in medium levels of involvement and high levels of embeddedness.

\subsubsection{Political Effects}

By locating themselves in a center position, an organization would be able to develop a organizational advantage and progress at the same speed with other organizational advancements. This is due to their position as a node via which knowledge passes. The successful collaboration between ABIA and the Lawyers Collective resulted in its becoming a case study and a point of reference for other Southern organizations. ABIA, in particular, has become an expert in South-South cooperation having published a book and hosted a satellite event at an international AIDS conference on the subject and their experience. It is now consulted by other organizations in the development of legal action taken by SouthSouth NGOs in related fields.

Proposition 3 posits that collaborations that are highly embedded will be positively associated with increase in influence. ABIA has indeed felt such political effects, since it has become an authority on South-South legal cooperation since its collaboration with the Lawyers Collective. 


\section{IMPLICATIONS}

The implications of this research are manifold. Firstly, it sheds light on a case of South-South NGO cooperation. Normally research in the area of South-South cooperation is political or economically motivated. In this case, the collaboration of two civil society groups from different developing nations are put in the spotlight. This is significant, in that it demonstrates an emerging social power that complements its emerging political and economic status. A new paradigm in global relations is taking place; interorganizational relationships at the international level are not just NorthNorth or North-South. Knowledge transfer and creation is increasingly taking place at the Southern level.

Secondly, this case adds to the literature on IP rights and access to essential medicines. A lack of access to ARVs has resulted in the proliferation of HIV/AIDS in the developing world (UNAIDS, 2010); whereas in the richer North, where access is easily achieved, new infection rates have stabilized or diminished. This discrepancy has resulted in a demand of Southern NGOs especially equipped to challenge the proprietary rights of ARVs with legal action. This study examines this social movement and a novel strategy in securing access via South-South collaboration.

Thirdly, this case enhances the literature on knowledge management and collaboration on non-profit organizations. As stated before, such literature focuses largely on for-profit organizations; there is an immense lack of insight on non-profits in this area. By providing a case study that demonstrates the potential of South-South collaborations, the author hopes to facilitate other such collaborations in order that socially stratified societies might be empowered via social means.

Fourthly, this study demonstrates that the proposed methodology (Hardy et al. 2003) is applicable to South-South collaborations, complementing their case study between a Palestine NGO and its collaboration with Northern-based organizations. It shows that the same strategic, knowledge creation and political effects take place at the 
Southern level as well. Furthermore, this study gives more credence to their theory that the degree of aggregated dimensions of involvement and embeddedness of a collaboration is a practical methodology to predict the types of collaboration effects that will take place. This has important implications to managers of Southern NGOs who seek to enhance and create new knowledge in order to serve their targeted social group. Seeing as they tend to lack many of the resources of their more generously funded counterparts, this study should be particularly relevant to the development of NGO management practices in order to meet organizational objectives.

Lastly, this study is important due to its methodological implications. It used a holistic qualitative approach in evaluating the collaboration, as research was based on not just archival research and the application of a qualitative methodology (Hardy et al., 2003), but also participant observation research. Via the latter methodology, the author was able to acquire an inside perspective of the collaborative effects of the collaboration between the Lawyers Collective and ABIA. In particular, the author observed the political effects of this collaboration when coordinating the logistics of a satellite event on South-South cooperation in the area of IP rights and AIDS at the 2009 IAS Conference in Cape Town, South Africa. This collaboration was one of the main highlights of the event, and civil society groups from all over the Global South had attended to learn from it. ABIA and the Lawyers Collective are considered authorities in this area, and their collaboration is perceived as a harbinger to a wider legal movement in the area of IP rights and health.

\subsection{LIMITATIONS AND SUGGESTIONS FOR FUTURE RESEARCH}

Several limitations of this study need to be addressed. Firstly, data was based partly on retrospective accounts of the collaboration surrounding the pre-grant opposition. This compounds the issue of accurately evaluating the dynamics of the relationship formed between SAHARA and ABIA. In order to be objective, the author focused on historical facts, rather 
than on the motives or perceptions of the participants of the collaboration. Secondly, the scope of the research is limited only to the impact of collaboration on only one of the NGOs involved in the collaboration; a more comprehensive study that includes the Lawyers Collective and SAHARA would be pertinent. Thirdly, this study focuses only on one collaboration and did not find other examples of comparison. As such, the scope was very narrow and generalizations about South-South collaboration cannot be made from this study. Nevertheless, it is the author's intention to address these limitations by carrying out a much more comprehensive study on a myriad of South-South collaborations to also present the effects of collaboration on SAHARA and the Lawyers Collective. Seeing as that the author has yet to find a study on the knowledge management and collaboration effects on South-South collaborations, the author still believe this study is pertinent in academic literature albeit its limitations in scope.

The author suggest that future research also examines other case studies of South-South civil society cooperation in certain areas that particularly affect the Global South. Examples include AIDS, other more prevalent epidemics in the South, slum initiatives, micro-financing, etc. Such research would shed light on Southern social empowerment in the context of the South's emerging political and economic influence. Southsouth social collaborations are relevant in that they speak to the clout of Southern political organizations like the BRICS, MERCOSUR and the African Union.

\subsection{Final Conclusions}

Based on the findings of this study, the collaboration between ABIA and Lawyers Collective in the area of intellectual property rights and health has produced all three types of effects predicted from knowledge management and collaboration literature. The case study involving the ABIA's pre-grant opposition against the patent application of tenofovir is a significant example of where strategic, knowledge creation and political 
effects all took place. Furthermore, the findings support the three propositions posited in Resources, Knowledge and Influence: the Organizational Effects of Interorganizational Collaboration (Hardy et al., 2003).

- Proposition 1: Collaborations that have high levels of involvement will be positively associated with the acquisition of distinctive resources

- Proposition 2: Collaborations that have high levels of involvement and high levels of embeddedness will be positively associated with the creation of knowledge

- Proposition 3: Collaborations that are highly embedded will be positively associated with an increase of influence.

\section{REFERENCES}

ABIA. (n.d.). Homepage. Associação Brasileira Interdisciplinar de AIDS. Retrieved November 30, 2011, from http://www.abiaids.org.br/.

ABIA. (2009). Intellectual Property Rights and Access to ARV Medicines: Civil Society Resistance in the Global South. Rio de Janeiro: ABIA.

Afuah, A. (2000). How Much Do Your Competitors' Capabilities Matter in the Face of Technological Change. Strategic Management Journal, 21 (3), 397.

Alavi, M. \& Leidner, D. E. (2001). Review: Knowledge Management and Knowledge Management Systems: Conceptual Foundations and Research Issues. MIS Quarterly, 25 (1), 107-136.

Anderson, Tatum. (2008, July 4). US, Indian HIV/AIDS Drug Rulings Could Reverberate in Brazil. Intellectual Property Watch. Retrieved November 30, 2011, from http://www.ip-watch.org/weblog/2008/07/04/us-indian-hivaidsdrug-rulings-could-reverberate-in-brazil/. 
Bartlett, N. \& Spar, D. (2005). Life, Death and Property Rights: the Pharmaceutical Industry Faces AIDS in Africa. Harvard Business Review. Retrieved on November 30, 2011, from http://hbr.org/product/life-deathand-property-rights-the-pharmaceutical-/an/702049-PDF-ENG.

BS Reporter. (2009). Brazilian Patient Group Files Opposition in India. Business Standard. Retrieved November 30, 2011, from http://www.business-standard.com/india/news/brazilian-patient-groupfiles-opposition-in-india/40876/on.

Bourdieu, P. (1993). Sociology in Question. London: Sage.

Bradach, J. (2003). Going to Scale: The Challenge of Replicating Social Programs. Stanford Social Innovation Review. Spring, 19-23.

Brand, A. (1998). Knowledge Management and Innovation at 3M. Journal of Knowledge Management, 2 (1), 17-22.

Brown, J. S. \& Duguid, P. (1991). Organizational Learning and Communities-of-Practice: toward a Unified View of Working, Learning, and Innovation. Organization Science, 2, 40-57.

Burt, R. (1992). Structural Holes: The Social Structure of Competition. Cambridge, MA: Harvard University Press.

Capozzi, M. M., Lowell, S. M. \& Silverman, L. (2003). Knowledge Management Comes to Philanthropy, The McKinsey Quarterly, 2.

Connell, N.A.D., Klein, J. H. \& Powell, P.L., (2003). It's Tacit Knowledge but not as We Know it: Redirecting the Search for Knowledge. Journal of the Operational Research Society, 54, 140-152. 
Dyer, J. (1996). Specialized Supplier Networks as a Source of Competitive Advantage: Evidence from the Auto Industry. Strategic Management Journal, 17, (4), 271-91.

Dyer, J. and Singh, H. (1998). The Relational View: Cooperative Strategies and Sources of Interorganizational Competitive Advantage. Academy of Management Review. 23 (4), 660.

Galaskiewicz, J. (1979). Exchange Networks and Community Politics. Beverly Hills, CA: Sage.

Gray, B. (1989). Collaborating. San Francisco: Jossey-Bass.

GTPI (n.d.). Homepage. De olho nas patentes. Retrieved November 30, 2011, from www.deolhonaspatentes.org.br.

Goozner, M. (1999, April 28). Third World Battles for AIDS Drugs: US Firms Oppose Generic Licensing. Chicago Tribune. Retrieved November 30, 2011, from http://www.aegis.com/news/ct/1999/ct990404.html.

Gulati, R. (1998). Alliances and Networks. Strategic Management Journal, $19,(4), 293-317$.

Gulati, R. (1999). Network Location and Learning: the Influence of Network Resources and Firm Capabilities on Alliance Formation'. Strategic Management Journal, 20, (5), 397-420.

Gulati, R., Nohria, N. \& Akbar, Z. (2000). Guest Editors' Introduction to the Special Issue Strategic Networks. Strategic Management Journal, 21, (3), 203-15.

Hamel, G. (1991). Competition for Competence and Inter-Partner Learning within International Strategic Alliances. Strategic Management Journal, 12, 83-103. 
Hamel, G., Doz, Y. L. \& Prahalad, G. K. (1989 January/February). Collaborate with Your Competitors - and Win. Harvard Business Review. 133-139.

Hardy, G. \& Phillips, N. (1998). Strategies of Engagement: Lessons from the Critical Examination of Collaboration and Conflict in an Interorganizational Domain'. Organization Science, 9, (2), 217-30).

Hardy, C. Phillips, N. \& Lawrence, T. (2003 March). Resources, Knowledge and Influence: The Organizational Effects of Inter-Organizational Collaboration. Journal of Management Studies, 40 (2).

Harris, G. (2011). Federal Research Center Will Help Develop Medicines. The New York Times. Retrieved November 30, 2011 from http://www.nytimes.com/2011/01/23/health/policy/23drug.html?_r=1\&hp.

Hayduk, H. (1998). Organizational Culture Barriers to Knowledge Management. In Proceedings of the Fourth Americas Conference on Information Systems, 591-593.

Hendry, G. (1996). Understanding and Creating Whole Organizational Change through Learning Theory. Human Relations, 49 (5), 621-41.

Hennart,J. F. (1988). A Transaction Cost Theory of Equity Joint Ventures. Strategic Management Journal, 9, 361-74).

Hickins, M. (1999). Xerox Shares Its Knowledge. Management Review. 88 (8), 40-45.

Hurley, T. \& Green, C. (2005 January). Knowledge Management And The Nonprofit Industry: A Within And Between Approach. Journal of Knowledge Management Practice.

Kinney, T. (1998). Knowledge management, intellectual capital and adult learning. Adult Learning, 10 (2), 2-5. 
Knights, D., Murray, E \& Willmott, H. (1993). Networking as Knowledge Work: a Study of Strategic Interorganizational Development in the Financial Services Industry. Journal of Management Studies, 30 (6), 975-95.

Laclau, E. \& Mouffe, C. (1985). Hegemony and Socialist Strategy. London: Verso.

Larsson, R., Bengtsson, L., Henriksson, K. \& Sparks,J. (1998). The Interorganizational Learning Dilemma: Collective Knowledge Development in Strategic Alliances. Organization Science, 9 (3), 285-305.

Lawyers Collective. (n.d.). Homepage. The Lawyers Collective. Retrieved November 30, 2011, from http://www.lawyerscollective.org/.

Médecins Sans Frontières (2011 July). Tenofovir Disoproxil Fumarate (TDF). Untangling the Web of ARV Price Reductions. 49-51.

Muzaka, Valbona. (2009). Developing Countries and the Struggle on the Access to Medicines Front: Victories Won and Lost. Third World Quarterly, $30(7), 1343-1361$.

Nahapiet, J. \& Ghoshal, S. (1998). Social Capital, Intellectual Capital and the Organizational Advantage. Academy of Management Review, 23 (2), 242-66.

Nohria, N. \& Eccles, R. G. (1992). Network and Organizations: Structure, Form and Action. Boston, MA: Harvard Business School.

Palella Jr., F.J. Delaney, K.M. Moorman, A.C. et al. (1998). Declining Morbidity and Mortality among Patients with Advanced Human Immunodeficiency Virus Infection. HIV Outpatient Study Investigators. New England Journal of Medicines. 338 (13): 853-860.

Powell, W W. (1990). Neither Market nor Hierarchy: Network Forms of Organization. In Staw, B. M. and Cummings, L. L. (Eds), Research in Organizational Behavior. Greenwich, CT: JAI Press, 295-336. 
Powell, W W \& Brantley, P. (1992). Competitive Cooperation in

Biotechnology: Learning through Networks?. In Nohria, N. and Eccles, R. G. (Eds), Network and Organizations: Structure, Form and Action. Boston, MA: Harvard Business School, 366-94.

Powell, W., Koput, K. \& Smith-Doerr, L. (1996). Inter-organizational Collaboration and the Locus of Innovation: Networks of Learning in Biotechnology. Administrative Science Quarterly, 41 (1), 116-46.

Prahalad, C. K. \& Hamel, G. (1990). The Core Competence of the Corporation. Harvard Business Review, 68 (3), 79-91.

Reis, R. (personal communication, December 4, 2011).

Reis, R. (personal communication, July 5, 2009)

Raaj, Neelam. (2008, July 6). Brazilian Group Opposes Gilead's AIDS Drug Patent. The Times of India. Retrieved November 30, 2011, from http://articles.timesofindia.indiatimes.com/2008-06-27/indiabusiness/27744588_1_drug-patent-tenofovir-patent-battle.

SAHARA. (n.d.). Homepage. SAHARA. Retrieved 30 November 2011, from http://www.aalhadpune.org/.

Sepkowitz, Kent A. (2001, June 7). AIDS - The First 20 Years. The New England Journal of Medicine. Retrieved on 30 November 2011, from http://www.nejm.org/doi/full/10.1056/NEJM200106073442306.

Sharratt, M. \& Usoro, A. (2003). Understanding Knowledge-Sharing in Online Communities of Practice, Electronic Journal on Knowledge Management, 1 (2), 187-196.

Teece, D. (1986). Profiting from Technological Innovation: Implications for Integration, Collaboration, Licensing, and Public Policy. Research Policy, 15, 785-805. 
Terto, V. (personal communication, June 10, 2009).

Trist, E. (1983). Referent Organizations and the Development of Interorganizatioal Domains. Human Relations, 36, 269-84.

UN Millennium Project (2005). Combating AIDS in the Developing World. Retrieved 30 November 2011, from: http://www.unmillenniumproject.org/reports/reports2.htm.

UNAIDS. (2010). Unite for universal access: Overview brochure on 2011 High Level Meeting on AIDS. Retrieved on 30 November 2011, from http://www.unaids.org/en/aboutunaids/unitednationsdeclarationsandgoals/ 2011highlevelmeetingonaids/.

UNAIDS. (2010). Global Report: UNAIDS Report on the Global AIDS Epidemic. Retrieved on 30 November 2011 from http://www.unaids.org/globalreport/Global_report.htm.

United Nations. (n.d.). Millennium Development Goals: AIDS. Retrieve 30 November 2011, from http://www.un.org/millenniumgoals/aids.shtml.

Warren, R. L., Rose, S. \& Bergunder, A. (1974). The Structure of Urban Reform. Lexington. MA: DC Heath.

Wasserman, S. \& Galaskiewicz, J. (1994). Advances in Sociat Network Analysis: Research in the Social and Behavioral Science. Thousand Oaks, CA: Sage.

Wells, J. R. \& Rabe, E. (2005, October 27th). The Pharmaceutical Industry in 2005. Harvard Business Review. Retrieved on 30 November 2011, from http://hbr.org/product/pharmaceutical-industry-in-2005/an/706423-PDFENG. 
Wernerfelt, B. (1984). A Resource Based View of the Firm. Strategic Management Journal, 5, 171-180.

Williamson, O. E. (1991). Comparative Economic Organization: the Analysis of Discrete Structural Alternatives. Administrative Science Quarterly, 36, 269-96.

WTO. (2011). TRIPS: Text of the Agreement on Trade-Related Aspects of Intellectual Property Rights. Retrieved 30 November 2011, from http://www.wto.org/english/tratop_e/trips_e/t_agm0_e.htm.

Yang, J. (2004). Job-related Knowledge Sharing: Comparative Case Studies. Journal of Knowledge Management, 8 (3), 118-126. 